\title{
Meaningfulness of Civic Education in Elementary Students with Models Contextual Problem Based
}

\author{
Mohamad Syarif Sumantri \\ Universitas Negeri Jakarta \\ Jakarta Timur, Indonesia \\ mohamadsumantri@gmail.com
}

\author{
Paijah Komala \\ Sekolah Dasar Negeri 04 Pamulang \\ Tangerang Selatan Banten, Indonesia \\ ijah.aloha@gmail.com
}

\begin{abstract}
The purpose of this research to improve meaningfulness and learning outcomes of civic education in elementary student through contextual problem based learning model. This study uses an approach in action research. The research subjects are the public elementary student at the fifth grade. The data collection is done in ways that observation to process data using observation and interviews and document analysis as triangulation. Each end of the cycle is evaluated the impact of actions. The analysed data is mix method, which is reinforced by the results of assessment tests to learn civic education. This is evidenced by percentage, the first cycle is completed, that is $59.38 \%$, increase in cycle II reached $80.63 \%$. Meaningfulness of learning of student in accordance learning the syntax of contextual problem based learning model was reached $83 \%$ in the second cycle. The results of this study indicate that the learning outcomes of civic education in elementary student at the fifth grade increased with the using of contextual problembased learning model other findings show that most students are more active and show interest in civic education.
\end{abstract}

Keywords-civic education; contextual learning; elementary student; problem based learning

\section{INTRODUCTION}

Citizenship is an important lesson and should be learned by every citizen, because in civic learning there is a lesson that studies about group life, nation and state and also learn about rights and obligations as citizens.

The main goal of civic education is to cultivate state knowledge and awareness, and to foster attitudes and behaviors that love the country. In addition, it aims to improve the quality of citizens who are virtuous, personable, independent, tough, intelligent, creative, skilled, and disciplined.

Through citizenship education, it is expected to be able to comprehend, analyze, and answer the problems faced by the people, nation and state of Indonesia consistently and continuously with the national goals and goals as outlined in the preamble to the 1945 Constitution. which we should be appropriate for civic education does not cause boredom and foster eager in learning. For example, the material of the unity of NKRI, we can use inquiry method such as problem based learning because this method is suitable to stimulate students to think critically, creatively, inductively, deductively because inquiry itself is essentially question and question.

\section{THEORETICAL}

Citizenship education is an effort to equip students with basic knowledge and skills with respect to the relationships between citizens and the state as well as preliminary education to defend the state in order to become citizens who can be relied upon by the nation and state [1]. Therefore learning civic education in elementary school is very important because students begin to know about the basic material concerning values, morals and norms that always have been remembered, so that elementary school teachers should embed good values. Civic education materials in the primary school curriculum focus on the development of democratic education, and have the following functions: 1) civic intelligence, 2) civic respocibility, 3) civic participation, 4) civic knowledge [2].

The civic education material is theoretical and abstract for elementary school age student so boring and saturate student, beside that teacher teach moral values in civic education just lecturing and trying to answer exam questions in textbook [3].

Tripodo and Setiani says that a student before receiving learning has an initial concept of the various phenomena around them and if the new concept received in the school has anything to do with the original concept of the student, then the learning will be easy to accept, if contrary to the original concept and concept new, then the students will be difficult to accept it even tends to refuse like pretending not to hear, ignore or out of class $[4,5]$.

The problem is how to find the best approach to convey civic education concepts so that students could use and remember longer concepts. Have civic education teachers been able to communicate effectively with students who are always asking about the reasons for something, the meaning of something and the relationship of what they are learning. How to open the thinking and diverse insights of all students so that the concepts they learn can be linked to real life. This is our challenge for teachers, especially civic education teachers.

Problem-based learning is a learning approach that begins with solving a problem but to solve that problem learners need new knowledge to be able to solve it. Problem-based learning has characteristics such as learning starting with problemsolving, usually the problem of having context with the real world, students in groups actively formulating problems and identifying their knowledge gaps, studying and searching for 
themselves material-related issues that is real [6]. The role of teachers in problem-based learning is to present problems, ask questions, and facilitate inquiry and dialogue or discussion.

There is a relationship between the concept of civic education learning, the characteristics and the advantages of contextual based PBL approach and the characteristics of elementary school students' learning. Theoretical and abstract civic education metrics, the cognitive developmental characteristics of elementary school students with concrete operational and PBL models that stimulate liveliness, fun and learning significance. Furthermore, the hypothesis of action can be formulated that the material civic education and meaningfulness of learning can be improved through contextual learning model of the problem.

\section{METHOD}

This research is a case study of classroom action research approach, using cycles starting from planning, acting, observing, reflecting, and continuing to re-planning as the basis for problem solving. The relationship between the four stages in this system is viewed as a cycle. Action research conducted in class V SDN 04 Pamulang Tangerang south with 32 students and research that lasted for 2 cycles. Cycle I and cycle II each consist of $4^{\text {th }}$ activity.

This research is divided into two kinds of data, those are quantitative data from the test score of civic education learning outcome of NKRI integrity with essay test form, and qualitative data for process monitoring action. Data collection techniques in this study were differentiated into two types of tests and non-tests, namely to collect test data civic education learning results in the form of description test, while to collect non-test data (learning process) is done by (1) observation, (2) documentation, and (3) interviews.

Analysis qualitative data used with data description, data reduction, data category or display and conclusion. Analysis quantitative data used with frequency distribution, percentage, and score of test result, then analyzed descriptively and presented in graph form. To obtain valid data on the data qualitative organized by triangulation through sources and methods. Focus of meaningful learning civic education consists of (1) the quality of the activity, (2) the enthusiasm of learning, (3) the understanding of the topic, (4) the attitude of the students in the utilization of civic education topics, (5) the opportunities for the concept of civic education to be transferred in different situations. Validation of civic education instruments test is examined by two civic education experts.

\section{RESULT AND DISCUSSION}

The result of the research based on data analysis on observation, interview and document analysis shows that learning problem based learning (PBL) based on contextual teaching encourages active students, students can respond to learning activities with their whole potential both mental and physical, so that civic education learning becomes fun, concrete, contextual and easy to understand. The use of this PBL model can develop innovative, integrated and contextual civic education learning. Based on the results of the test by comparing the initial test with the final test shows that learning civic education on the topic of the NKRI integrity increase with a score of $59.38 \%$ to $80.63 \%$.

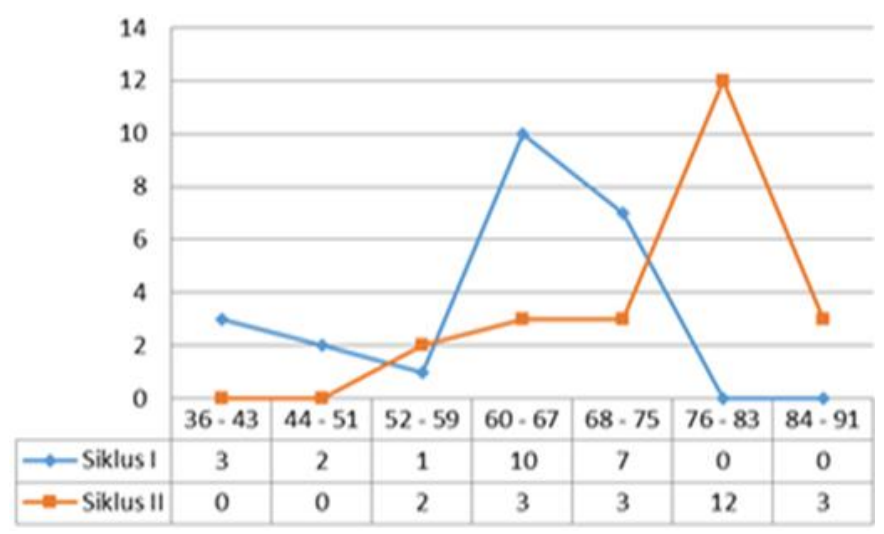

Fig. 1. Comparison of learning outcomes civic education students cycle I and II.

Based on data analysis PBL model shows students in learning the concept of civic education showed a positive impact of facilitating students in communicating both written and spoken, students become more critical, the development of scientific attitudes in learning the concept of civic education. The application of PBL method shows that teachers can understand in terms of characteristics of students of primary school age as a whole, this is because the PBL method requires the activeness of teachers and students, PBL in learning civic education encourages students to explore information and make decisions based on data that students find and finally able to draw conclusion precisely [7]. In addition, teachers can be focus to act as facilitators who guide and direct students in the learning process, PBL method has potential to activate students because the classroom situation becomes active, giving students the opportunity to test their skills in a creative way.

The initial ability of civic education learning outcomes average score of 62.75 under the completeness criteria is at least 75. And improved after the first cycle of action by following the five steps of contextual learning problem based learning. The first stage is the process of student orientation on the problem. At this stage the teacher explains the purpose of the activity, and explains the necessary learning resource materials, motivates the student to engage in problem-solving activities to end with the findings and issues. The second stage, organizing the students. At this stage the teacher divides the students into groups, the teacher facilitates the students in preparing the definition of the topic and organize activities related to the problem. The third stage, teacher have guiding individual and group investigations. At this stage, the teacher attempts to encourage students to collect required information from various learning resources such as books, internet and so on. Students continue to carry out discussion activities to get explanation and problem solving in learning the topic of civic education. The fourth stage, developing and presenting results of observation. At this stage the teacher seeks to assist students in planning and preparing reports, documentation or models, and helping them share their work with their peers, and the fifth stage, students are encouraged to practice analysing and evaluating their processes and observations as a product of problem solving. The research findings show the first cycle of 
civic education learning outcomes on average the students still have not reached the target expected by researchers and collaborators. The average acquisition of students reached 68.88 .

In the second cycle obtained that the different learning outcomes with the same civic education theme and already meet the criteria of successful research is to achieve average learning outcome civic education of 86.63. The result has exceeded the minimum completion target of 75 . So that researchers and collaborators agreed to stop observations until cycle II. Also the questionnaire score about the meaningfulness of learning civic education students showed a significant improvement with score 83. Increased when compared with the initial score only reached 59 points from a maximum score of 100. In addition, observation data and learning process documents based on the results of reflection of researchers and collaborators showed enthusiastic changes in students class $\mathrm{V}$ in studying civic education.

Furthermore, we have been using the mastery learning approach to learning civic education based on the number of students then the results of data analysis show table I as follows:

TABLE I. MASTERY AND MASTERy PRE-CYClE COMPETITION, CYCLE I AND CYCLE II

\begin{tabular}{|l|l|l|l|l|l|}
\hline Mastery & Pre-cycle & Cycle 1 & Cycle 2 & Cycle I & Cycle 2 \\
\hline Complate & 13 & 19 & 29 & $59.38 \%$ & $90.63 \%$ \\
\hline $\begin{array}{l}\text { Not } \\
\text { Complate }\end{array}$ & 19 & 13 & 3 & $40.63 \%$ & $9.38 \%$ \\
\hline Total & 32 & 32 & 32 & $100 \%$ & $100 \%$ \\
\hline
\end{tabular}

Based on the results obtained can be said that the use of contextual learning model problem-based learning has succeeded in improving student learning civic education outcomes and meaningfulness of learning. Barell asserted by using contextual learning problem based learning (PBL), to be better and fun [8]. Based on the students enthusiastic student's overall observation becomes increasing and the concentration of students becomes more focused. Based on data triangulation shows students feel happy because given the opportunity to express ideas and assisted with the use of simple student worksheets and in accordance with their understanding in solving problems and find the concept of NKRI unity suitable with everyday life in their environment.

\section{CONCLUSION}

Based on the findings of the research, there is an increase in the learning outcomes of civic education through learning problem based learning in grade $\mathrm{V}$ students. This can be seen from the change of observation scores in cycle 1 to cycle 2 through the civic education learning outcomes and the observation of the meaningfullness of civic learning education showed enthusiasm in the learning process of civic education with contextual based problem based learning model. The findings show that students tend to be happier, enthusiastic, active, the concept of civic education can be applied in different situations, students to civic education material is important and easy to understand.

\section{REFERENCES}

[1] A. Wahab, Pendidikan Pancasila dan Kewarganegaraan, Jakarta: Universitas Terbuka, 2008.

[2] R.G. Niemi and J. Junn, Civic Education: What Makes Students Learn May, USA: Yale University Press, 2005.

[3] Y. James, "Civic Education: What Schools Can Do to Encourage Civic Identity and Action," Journal Applied Developmental Sciene, vol. 15, no. 2,2011 .

[4] A. Tripodo and R. Pondiscio, "Seizing the Civic Education Moment Educational Leadership,” vol. 75, no. 3, pp. 20-25, 6p, Nov 2017.

[5] M.Y. Setiani and A.M. MacKinnon, "A community of inquiry-based framework for civic education at Universitas Terbuka, Indonesia,' Distance Education, vol. 36, no. 3, pp. 351-363. 13p, November 2015.

[6] M.S. Nyet and R. Mapeala, "The effects of thinking maps aided problem based learning on motivation towards science learning among fifth grades," Journal of Baltic Science Education, vol. 16, no. 3, p379-394. $16 \mathrm{p}, 2017$.

[7] Y. Bei, W. Minhong, A.W. Kushniruk, and P. Jun, "Deep Learning towards Expertise Development in a Visualization-based Learning Environment," Journal of Educational Technology \& Society, vol. 20, no. 4, p233-246. 14p, 2017.

[8] J.F. Barell, Problem-Based Learning: An Inquiry Approach, New York: Corwin Publisher, 2006. 